\title{
Research on Communication Ethnography in Toba Batak Communities in Samosir District, North Sumatera Province Regarding Analysis Speech Act in Death Saurmatua Ceremony
}

\author{
Hernawaty Nancy A.Purba \\ Indonesian Language and Literature Education STKIP Riama Medan, Indonesia
}

\begin{abstract}
This study aims to determine the type of speech acts used in the death ceremony saurmatua Toba Batak customs and interpret the cultural values in it. The method used in this research is descriptive qualitative method. Data collection techniques carried out using literature study, observation and interviews. Data analysis techniques are preparing the object of study, identifying and translating data into Indonesian, observing words or sentences, classifying data, and then making conclusions. The results were obtained as many as 41 types of illocutionary speech acts data, which includes the types of: directive utterances (speech requests, orders, invite, force, suggest, push, order, collect, order, order, request, challenge, give an order) of 21 data $(51.22 \%)$, representative speech (speech demands, acknowledges, shows, reports, gives testimony, mentions, speculates) of 16 data (39.02\%), and expressive speech (speech thanks, complains, congratulates, flatters, praises, blames, and criticizes) of 4 data $(9.76 \%)$. Speech acts in the Batak Toba Saurmatua Death Ceremony are dominated by directive speech acts.
\end{abstract}

Keywords: Speech Analysis, Saurmatua, and Pragmatics.

DOI: $10.7176 / \mathrm{JEP} / 10-32-07$

Publication date: November $30^{\text {th }} 2019$

\section{Background}

Indonesia has various tribes, one of which is the Batak tribe. The Toba Batak tribe is a tribe found in North Sumatra Province, and is one of the sub-ethnic groups besides the Simalungun, Karo, Mandailing, Nias and Pakpak Batak. One of the differences between sub-ethnic groups is the language and geographical location of the area. The implementation of the Toba Batak community is very different from some areas known as the Holbung, Silindung, and Humbang Batak. The fundamental difference in these three regions is in terms of the implementation of the Toba Batak tradition, especially in the distribution of jambar (awards) and the distribution of ulos (shawls) while the similarity is the communication tool used and the language used is the Toba Batak language.

Speech acts are actions that occur in every process of communication using language. Language is a communication tool that has an important role in socializing with fellow humans to communicate with other humans in conveying the intentions and objectives of each through language.

Some of these ethnic languages are the daily language of the people and are used at traditional ceremonies. The Toba Batak language is one of the regional languages in Indonesia that is still used by the supporting community in their daily interactions. This language can be said as the first language in social communication from various layers of Toba Batak society. Batak tribe is a tribe known as the clan as patrilinier lineage which for generations have different clan lineages based on their lineage.

Ceremony of the death of saurmatua for the people of Toba Humbang Batak, Toba Silindung Batak and also Toba Holbung Batak who are inseparable from the provision of ulos, especially the death of saurmatua Toba Humbang Batak in the town of Sidikalang. Judging from the number of ulos given in accordance with the conditions generally contain almost the same meaning, but the difference is the expression of opening tujung. The phrases when opening the tip will be examined through speech acts.

The term saurmatua is a term for a person who has died in a condition where all his children are married and have children (grandchildren of the deceased person). Ulos tujung was given by hula to the deceased wife. Conversely, if the deceased woman (borua) then the one giving the handkerchief is the "hula-hula", while the ulos tujung is given by the "bone". However, there are certain places in Toba Samosir (Batak Holbung) that do not apply. If the deceased is a male (baoa) then the one who gives the Saput ulos and the Sampe Tua ulos is only from the Hula-hula part. Vice versa, if the deceased woman (borua) then who gives ulos Saput and ulos Sampetua is the Hula-hula. Ulos are given at the morning before the big event. The types of ulos used at the ceremony of the death of saurmatua Batak Toba custom are ulos Saput, ulos Tujung, ulos holong, live yeast ulos, ulos sampe and other types of ulos. The speech act of giving ulos at the death ceremony of Saurmatua Batak Toba custom is inseparable from the intention conveyed by the speaker to the listener. In analyzing speech acts, it is important to realize how important the context of speech or expression is.

Research on speech acts has been done by several previous researchers. However, this study has a difference from previous studies, the researcher examines speech acts during the event at the time of opening 
tujung.

\section{Research methods \\ Research Methods and Design}

This research was conducted using ethnographic methods. Ethnographic method is one of the qualitative research methods, ethnographic methods are used to examine human behavior related to cultural development. Literally, ethnography means writing or reporting on an ethnic group written by an anthropologist on the results of fieldwork for months or years. Ethnographic research methods are considered capable of exploring information in depth with extensive sources. With the technique of "participatory observatory", ethnography becomes a unique research method because it requires the participation of researchers directly in a particular society or social community. Ethnographic methods are also called qualitative methods, qualitative methods are a paradigm of Naturalistic inquiry or natural inquiry. As a natural paradigm, qualitative methods use criteria of relevance. This relevance is the significance of the person to the real environment. The effort to find certainty and authenticity is important in scientific research. This natural paradigm tries to find out by analyzing data obtained systematically. This natural research model tries to find empirical data from interviews and observations in the field (Denzin, 2009). This research was conducted in the village of Huta Hotang, Onanrunggu District, Samosir Regency, North Sumatra Province.

\section{Population and Sampling Techniques}

The study population was the entire Toba Batak community in Samosir Regency, North Sumatra Province, and the sample of this study was the people who carried out the Saurmatua death ceremony.

\section{Data and Data Sources}

The data in this study are primary data and secondary data. Primary data is a variety of information and information obtained directly from the source, namely the family, the local community, and traditional leaders who are used as research informants. This type of data includes information and information about the death ceremony of saurmatua Toba Batak. Secondary data is a variety of theories and information obtained indirectly from the source, in addition to secondary data is also a complementary and comparative data. Secondary data is meant in the form of data in the form of reports, books, scientific articles, seminar results, and others. These data help researchers to find out the history, philosophy, and background of the death ceremony of saurmatua Batak Toba.

Sources of data in this study can be divided into two, namely: oral data sources and written data sources. Oral data sources are data obtained through direct observation and interviews with informants. The informants in question are: the family, the local community, and traditional leaders. Sources of written data refer to written sources of the Batak Toba saurmatua death ceremony. The data source uses words, verbs, and phrases in the words spoken from the source of the informant, parhata or traditional figure in the ceremony of the death of the Batak Toba saurmatua.

\section{Research Results and Discussion}

The speech act at the ceremony of the death of the saurmatua Batak Toba custom is inseparable from the intention conveyed by the speaker to the listener (listener). In analyzing speech acts, it is important to realize how important the context of speech or expression is. According to Siahaan, Dalihan Na Tolu used in every traditional ceremony of the Toba Batak people, without Dalihan Na Tolu a ceremony cannot be called a traditional ceremony. Dalihan $\mathrm{Na}$ Tolu has three things associated with giving ulos at the event of death saurmatua Toba Batak, which includes: 1) Saput ulos are given to the deceased as a sign of separation given by the hula-hula/uncle. 2) The granting of ulos tujung given by the hula-hula part to the deceased family, and 3) The granting of ulos holong given by the hula, rerobot bone and even Bona ni Ari including from spoiled children / hula-hula ni na marhaha maranggi to family who died. 


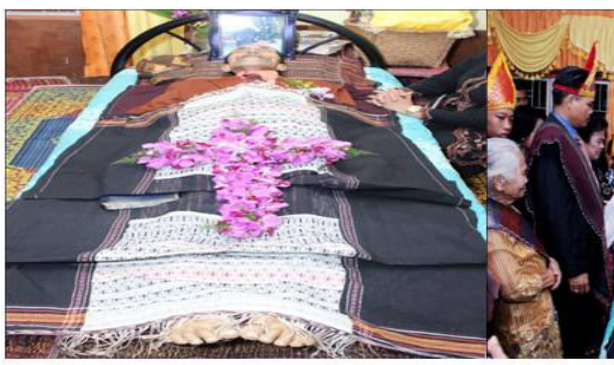

Fig. 1

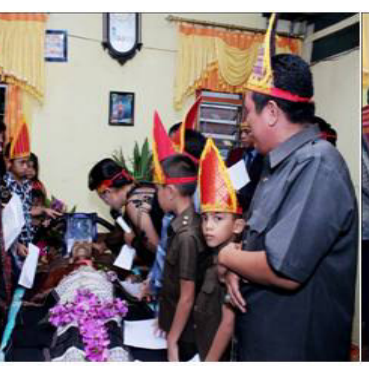

Fig. 2

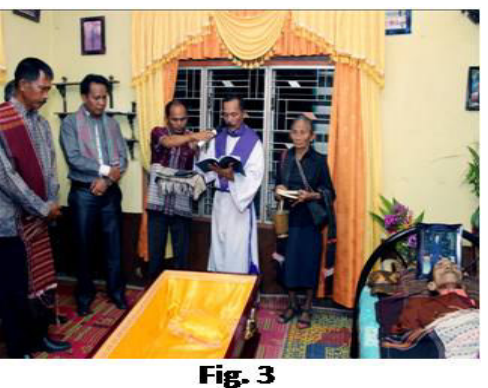

Fig. 3

Information Fig. :

Fig-1. Corpse still lying down on the rusbang

Fig. 2. Corpse surrounded by offspring and family

Fig. 3. The Corpse coffin was blessed by the church caretaker before the Corpse was put into the coffin

Here is one of the utterances uttered by hula-hula when they want to put tujung in the event of the death of the Batak Toba saurmatua custom:

"Di hamu pomparan ni Lae nami on. Di son hupasahat hami tu hamu sada ulos panggabei, sai mangulosi panggabean ma on, mangulosi parhorason, mangulosi daging muna dohot tondimuna sude pomparan ni lae on. Horas ma dihita sude. Meaning: "For all the children of Lae, here we convey a piece of ulos called" blessing "to cover all families and to give abundant blessings and health to the family".

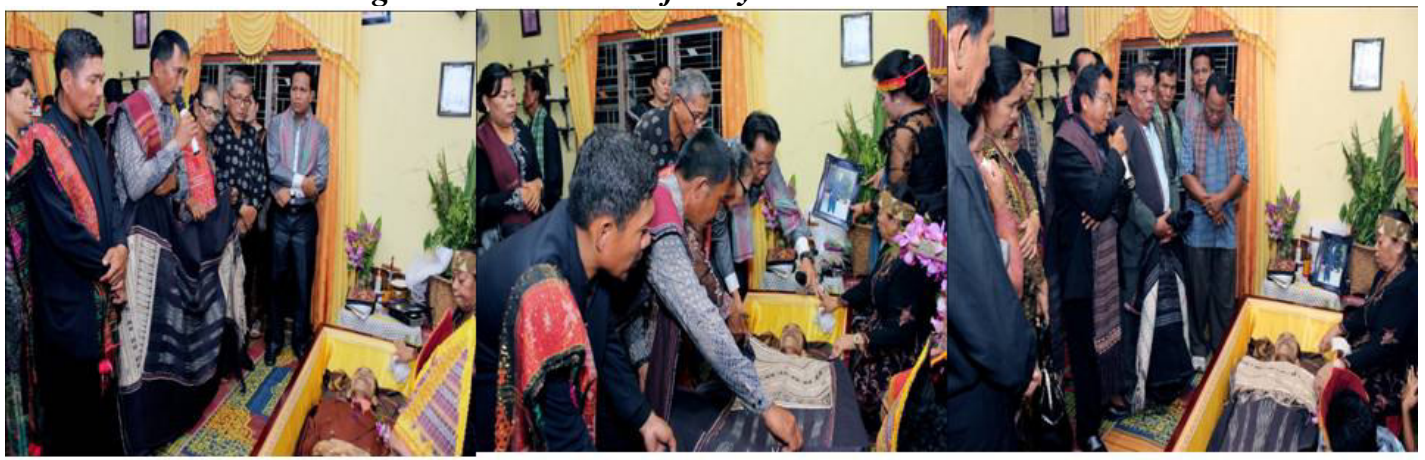

Fig. 4

Fig. 5

Fig. 6

Information Fig: :

Fig. 4. The uncle before pairing the ulos saput first conveyed a word or two to the descendantsand family left behind

Fig. 5. The uncle paired the ulos saput on the body corpse

Fig. 6. Part hula-hula before pairing ulos tujung to sister first convey a word to the descendantsand family left behind 


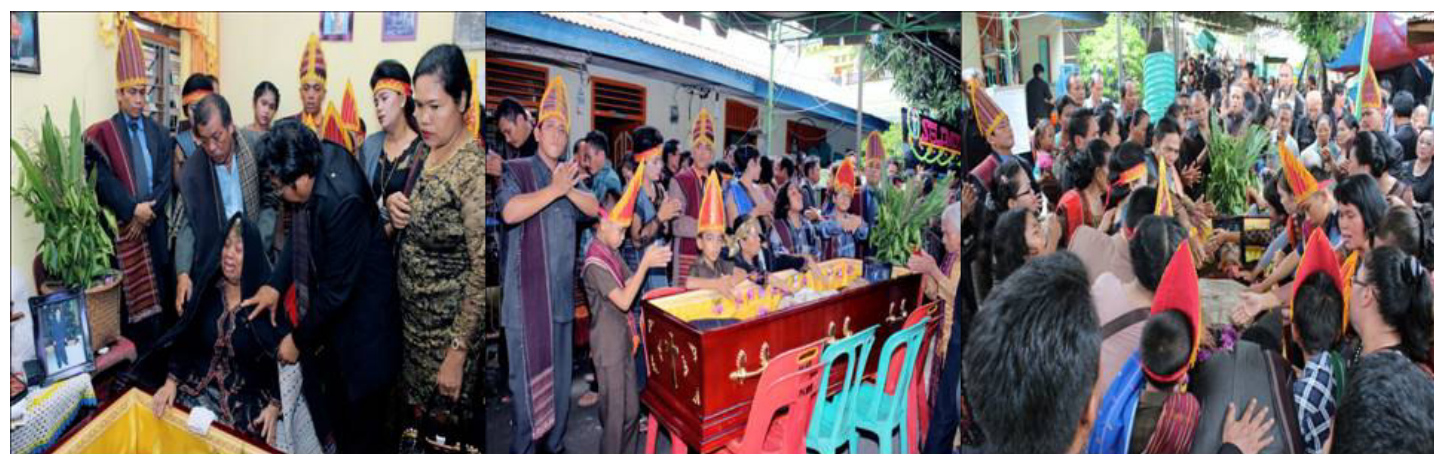

Fig. 7

Fig. 8

Fig. 9

\section{Information Fig. :}

Fig. 7. Part hula-hula pair ulos tujung to sister

Fig. 8. Corpse was taken out of the house (on page)

Fig. 9. Corpse dikelilingi by his descendants and family

The death ceremony in the tradition of the people Toba Batak

In the Toba Batak tradition, people who die will experience special treatment, summarized in a traditional ceremony of death. The ceremonies of death are classified according to age and status of the dead. For those who died while still in the womb (mate di bortian) have not received customary treatment (immediately buried without a coffin). But if you die when you are a baby (mate poso-poso), die as a child (mate dakdanak), die as a teenager (mate bulung), and die as an adult but not yet married (mate ponggol), all of the deaths received customary treatment: the body was covered with a piece of ulos (a typical woven cloth of the Toba Batak people) before being buried. Ulos corpse for friends poso-poso came from his parents, while for mate dakdanak and mate bulung, ulos from the bones (brothers and sisters of the mother) of the dead. Death ceremonies are increasingly full of customary treatment when people who die:

1. Has been married but does not have children (mate diparalangalangan / mate punu)

2. Has been married to leave his children are still small (mate mangkar)

3. Already have children who are adults, some have even married, but have not yet made a granddaughter (mate hatungganeon)

4. Already have grandchildren, but there are still children who are not married (mate sarimatua)

5. Having a granddaughter does not have to be of all her children (mate saurmatua).

Saurmatua became the highest level of ceremonial classification, because it died when all of his children were married. Indeed there is still the highest death rate above it, namely mate saurmatua bulung (dies when all of her children have been married, and has given not only grandchildren, even great-grandchildren of their sons and of their daughters. But both are considered the same as the ideal concept of death (dying by not having dependents of children anymore).

\section{Saurmatua ceremony among the Toba Batak people}

When someone in the Toba Batak community dies in saurmatua, it is only natural for the relatives to hold a family meeting (martonggo raja) as soon as possible, discussing the preparation for the procurement of the saurmatua ceremony. Relative parties comprise the elements of the Natolu Transfers. Dalihan Natolu is a system Batak community social relations, consisting of three groups of kinship elements, namely: the hula-hula (family members of the family of the wife), the dongan tubu (the group of people, namely: friends or relatives), and the boru party (the group of people people from the clan side of the husband of each of our sisters, family of the father's side). Martonggo Raja is carried out by all parties in the yard outside the funeral home, in the afternoon until finished. The local community (dongan sahuta) was present as a listener at the meeting (usually it would help in organizing the ceremony).

The meeting discussed the determination of the time of the ceremony, the location of the funeral, the customary ceremony after the burial, and the technical needs of the ceremony by the division of tasks. Technical requirements regarding the provision of ceremonial equipment such as: procurement of coffins, rental of musical instruments and music players, cutlery and dishes for those attending the ceremony, etc. 


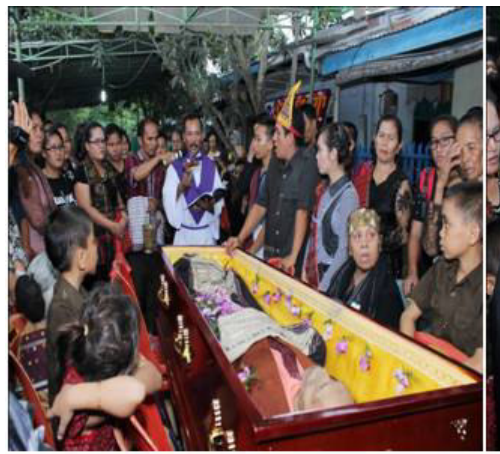

Fig. 10

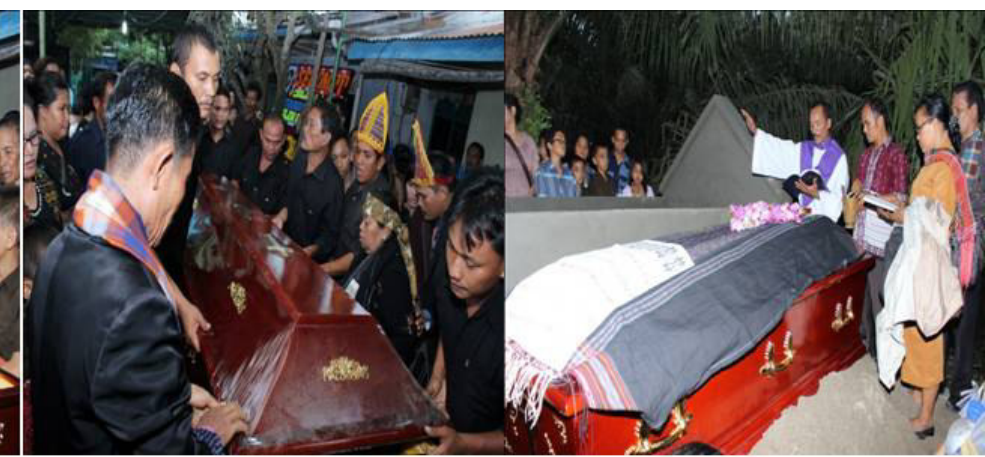

Fig. 11

Fig. 12

Information Fig: :

Fig. 10. The church blessed the corpse before corpse closed

Fig. 11. The corpse in a closed casket to be sent to the departed funeral

Fig. 12. Pengurus gereja bless his burial place before the coffin is inserted into the funeral.

\section{Implementation of the Death Ceremony of Saurmatua}

The implementation of the ceremony depends on the length of time the body was buried. Ideally held when all the sons and daughters of saurmatua dead and the hulahula are present. However, because many Batak people have wandered, often forced to for days delay the implementation of the ceremony (before being buried), in order to wait for the arrival of their children who have lived far away. Things like that in Martonggo the king can be used as a consideration to decide when the peak of saurmatua ceremony will be held before it is buried. While waiting for the arrival of all family members, it can be accompanied by a non-custom event, i.e. accept the arrival of mourners (such as non-Batak people). On the appointed day, the Saurmatua ceremony takes place in the afternoon, in a large open space (ideally on the funeral home). The body that had been put into a coffin was placed in the middle of all the children and grandchildren, with the position of the coffin of the foot towards the exit of the house. On the right of the coffin are boys with their wives and children, and on the left are daughters with their husbands and children. This is where the series of saurmatua death ceremonies begins. When all mourners from among the indigenous people have come (ideally before the lunch). The banquet is an occasion for the ceremony organizer to provide food to the mourners in the form of rice with side dishes in the form of sacrificial animals (buffaloes, cattle, or pigs) which were previously prepared by the parhobas (people assigned to cook all food during the party). After the banquet, a ritual of sharing jambar (part rights or acquisition rights of common property) is carried out.

Jambar consists of four types, namely: juhut (meat), hepeng (money), tortor (dance), and hata (speaking. jambar juhut is considered to replace jambar hepeng, but for families of esteemed social status, jambar hepeng is usually present.The order of jambar distribution begins with jambar juhut distribution, the meat used as jambar jahut is buffalo or horse, but the meat is also cut by the parhobas., divided in a raw state.

Universally, the distribution of jambar juhut is:

1. Chief $(u l u)$ for customary king (currently presenters during ceremonies)

2. Neck (rungkung or tanggalan) for boru parties

3. Thighs and legs (soit) for Dongan Sabutuha

4. Backs and ribs (somba-somba) for hula-hula,

5. The back (ihur-ihur) for hasuhuton. The dongan sahuta (friends in the village), pariban (our wife's brother and sister) and ale-ale (friends in the village), are counted the same as the dongan sabutuha.

After the rite of jambar juhut rite, continued the ritual of jambar hata in the form of the opportunity for each party to give words of comfort to the children of the dead saurmatua (hasuhuton). The word order starts from the hula-hula, followed by the dongan sahuta, then boru/bere, and finally dongan sabutuha. Every change of words of consolation, interspersed with the ritual of jambar tor-tor, namely the rite of the manortor (dancing tor-tor dance). Tor-tor is a traditional Batak dance. The usual torsion dance accompanied by music from the gondang sabangunan (traditional Batak musical instrument). Gondang sabangunan is a traditional Batak music orchestra, consisting of a set of instruments namely: 4 ogung, 1 hesek, 5 tagading, 1 odap, 1 gondang, dan 1 sarune.

In recent times, it is increasingly unclear what is required as equipment to be provided in the saurmatua death ceremony. Whereas in the 1980 s, if the dead saurmatua had to be complete "marsanggul marata" (sijagaron) placed in ampang (baskets) consisting of:

1. Boni sitamba tua (indicates many derivatives).

2. Miak-miak (candlenut which shows the spirit of the ancestors), 
3. Gantang (signifies having tweeted)

4. Baringin (signifying having a daughter and grandchildren)

5. Pira ni manuk (chicken eggs that signify good life)

6. Sanggar (signifying all the livelihood of the deceased so far has been obtained by good means)

7. Ampang indicates that the deceased was Saurmatua, ampang placed near the deceased's head

8. Suhut (misfortune family parties give the custom of respect in the form of food consisting of : tandok (chopsticks) containing 3 pieces of hazelnut, one egg, complete betel and money in an even number to pargonsi, received by parsarune (sarune blower) as group leader. Candlenut symbolizes the spirit of ancestral spirits, the egg symbolizes unity and good living, money and betel.

Now the Toba Batak people understand the saurmatua ceremony not to worship the parents so that the power of sahala is given to their children and grandchildren, but as an expression of gratitude to God for the gift of longevity to those who died in saurmatua. Whereas the concept of religious death in saurmatua as an "ideal death" is still maintained, because the socio-cultural orientation of today also considers death at a very old age to be the best death. In addition, the motivation for the procurement of the saurmatua death ceremony at the present time is directed as their traditional spiritual maturity. This was realized because in the saurmatua death ceremony the Batak people could gather with the whole extended family.

The idea of spiritual maturity they got after reflecting on the saurmatua ceremony became a form of thanksgiving from all the children and grandchildren of people who died to God, no longer to the spirits of the ancestors. There are also Christian Batak people who disagree with regard to the obligation to carry out the saurmatua ceremony, because it lacks sense and has no clear purpose. The saurmatua ceremony as an "ideal death" would be inappropriate with the understanding of the Christian faith if it was dominated by the desire to "show off". Moreover, it often happens, the family has "gone all out" to pay for the care of his parents from the start of illness to death, but still have to "all out" pay for saurmatua ceremonies to meet the demands of adat. Customs should not be a burden.

On the occasion of the tulang manortor (the deceased mother's brother), cover the live yeast ulos directly to the body of the corpse. Besides that bona tulang (hula-hula from the family of the late grandmother's brother) and bona ni ari (hula-hula from the family of the deceased grandfather's mother) also provide ulos (usually ulos sibolang). Ulos was developed on top of a coffin, as a last sign of affection. Then the hula-hula specifically mangulosi (pinning ulos) to the boru and hela (son-in-law) as a symbol of blessing that he said.

Hula-hula give ulos sibolang as ulos sampetua to the wife or husband left behind, by laying on the shoulders. If the person who has died has been left behind by his wife or husband, of course ulos no longer need to be given). Then hula give ulos summon to all offspring, by attaching ulos (alternately for a moment) on the shoulders of each of the oldest boys to the youngest (the last being given back to the oldest boy with the words of blessing). Hula-hula give ulos sibolang as ulos sampetua to the wife or husband left behind, by laying on the shoulders. If the person who has died has been left behind by his wife or husband, of course ulos no longer need to be given). Then hula give ulos summon to all offspring, by attaching ulos (alternately for a moment) on the shoulders of each of the oldest boys to the youngest (the last being given back to the oldest boy with the words of blessing). Just as the hula did, the bones of each hasuhuton also performed the rite. Then each woman from the group of bone manortor while upholding boras sipiritondi (plain flour rice which means giving a blessing and strengthening tondi), to then be handed over to the hasuhuton. While the other invited groups (dongan sabutuha, boru, bere, pariban, friends from the hasuhuton) in turn were invited to the manortor (see table). But they did not carry out a ritual of giving gifts. After jambar tor-tor of all mourners finished, next are the words of expression in response to the hasuhuton to each party who gave jambar hata and jambar tortor earlier. Next, one of the suhut uttered a jambar hata reply (mangampu) and also thanked all parties who had helped the implementation of the ceremony. Every transition is able from one party to another, interspersed with the rite of the manortor.

Manortor done by approaching each party who has attended the ceremony, as a sign of respect as well as asking for blessing. After all the rites have been carried out, the traditional ceremony is ended by handing over the last ritual (a funeral in the form of a short service) to the church. Worship can be carried out at that place, or when the body reaches the burial site. This adjusts the conditions, but the principle is the same. So before the coffin is put into the hole (which has been dug before), a short service is led by the church. It can be started from opening hymns, sermons, closing hymns, and closing prayers from the church. Then the body that was in a closed coffin was buried. 


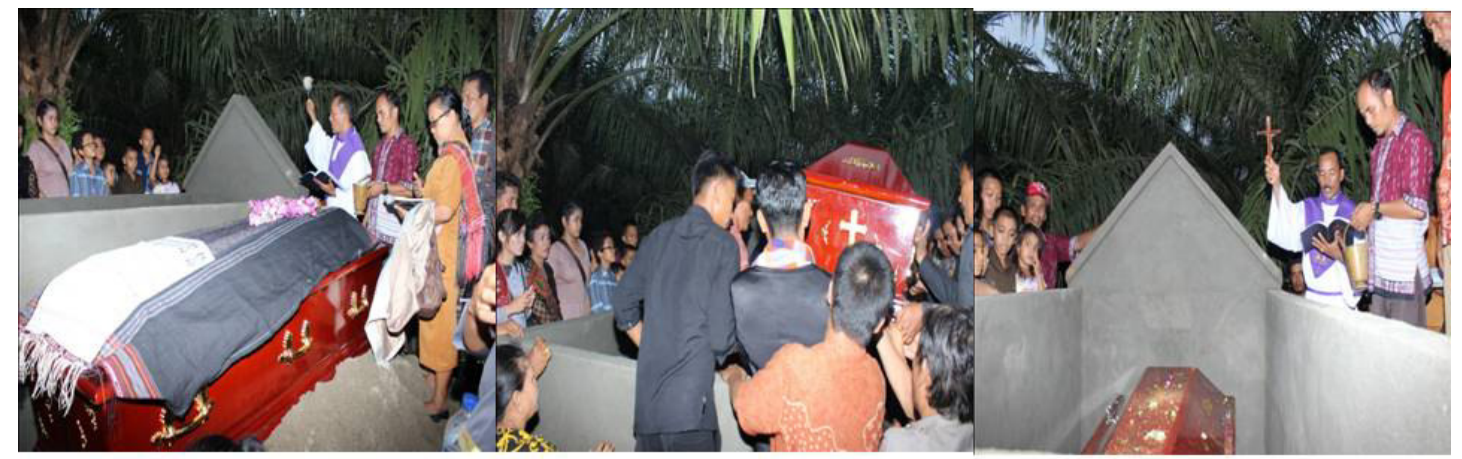

Fig. 13
Fig. 14
Fig. 15

\section{Information Fig.:}

Fig. 13. Church part bless his funeral before the church is inserted

Fig. 14. The church box dimasukkan put in his burial place

Fig. 15. The church caretaker bless his burial place before the coffin was buried.

\section{Opening Tujung (Ungkap Hombung)}

Opening tujung (Ungkap Hombung) is a traditional ritual that is done after returning from the cemetery. Adat opening tujung (Ungkap Hombung) is usually done at home. Adat opening tujung (Ungkap Hombung) is a rite of giving part of the property left by the deceased (sharing inheritance) to give to the hula-hula. But regarding the tradition said this hombung, already has a variety of understanding in the present. Ideally without being reminded by the hula, Opening tujung (Ungkap Hombung) can be discussed or a few days afterwards. Any which will be given to opening tujung (Ungkap Hombung), a family whose parents' death is classified as saurmatua should bring happiness to the hula-hula.

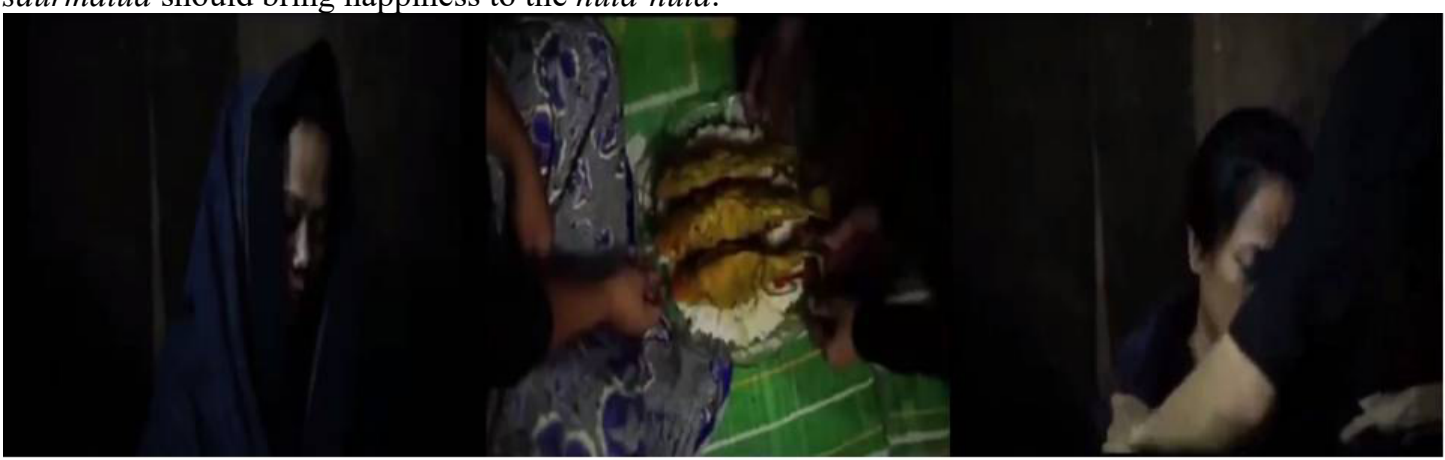

Fig. 16

Fig. 17

Fig. 18

\section{Information Fig: :}

Fig. 16. The wife of the deceased in the condition of use tujung

Fig. 17. Before tujung opened, the hula-hula gave goldfish as custom Toba Batak

Fig. 18. The hula-hula opened tujung

Before the opening ceremony is held, first it is opened with a prayer by protocol. Then the party hula convey sipanganon by saying the words:

"Diho ito, ngabinaen tujungmu ima tanda holongni rohannami di ho, nadohot do hami hulahulam marhabot ni roha ito, tarlumobi au ibotom. Disitaononmon parborhatni lae naburjui tonani oppungta sijolo-jolo tubu do on ito, molo tung tinujung ni boru manang ibotoniba ingkon ungkaphondo ido gokni adatna asa hatop lao akka arsak niroha dohot lungun ni roha sian ibotokku dohot akka iberekku. Meaning: For you, my brother, we have put on a veil as a symbol of how much we love you, that we are sorry for you, especially I am your brother. In your pain, for the departure of the late good laeku. As the message of our ancestors from time immemorial, if it is worn a veil for boru / itoku must be exposed. For the sake of completeness of customs. To keep the sadness and sadness away from itoku and frozen.

Then tujung is opened, by delivering a speech:

"Attong hubukama tujungmu ito, sai hatopmua dipamalum Tuhan akka nahaccit, nabernit naro tu ibotoku (pihak tulang memberikan air putih untuk diminum). Meaning: Now that I 
reveal your veil, may God restore the pain and pain that it feels.

Then do a facial wash by saying the words:

"Huapus ma ilum itoku, sai dipalaho Tuhattama akka naholom sian parnidaanmu dohot sian roham, sai binarma bohimi itoku tujoloanniarion, jala akka silasnirohama dilehon Tuhatta tuhamu tujoloanon. Meaning: I wiped your tears itoku, may God keep the darkness from your sight also from your heart. Give your face back to itoku day that will come. May happiness be given by God for you in the future.

Then it is done by putting rice on the head by saying the words:

"Pirma tondini itoku, sai dilehon Tuhanma hahipason di ho, margogo maho mandalani ariari ni ngolum pature-ture akka berekon. Meaning: "Be strong in your heart, may God always provide health for you. Be strong and live your life for all of you.

Ends by delivering rhymes with the words:

"Ikkon jumpangmasongonnani dokni natua-tua, tinapu bulungni siarum baen uramni porapora, nalungun ikkkon malum, sai tibu ro silasni roha. Bagotnamadungdungma tu pilo-pilo namarajar, salpumasude nalungun hatopma ro tuhamu najagar. Meaning: as the elders say, picking siarum leaves, making spices of fish, soreness and sadness must be healed, may happiness grow fast. Enau that can be achieved in a small palm tree, ends the feeling of sadness, soon there is goodness for you.

Then the words conclude by saying the words:

"Jala simpulanku do hataku songon didok natua-tua, eme ditambatuama parlinggomanni si boro, dilehon Tuhattama dihamu tua jala sude hita diparorot. Emmatutu (answer those present). Meaning: Paddy the old tamba, the tadpole's shelter, God bless, we are all protected. Amen (answer present).

words:

Then repeat eating (after eating repeat) then the wife first conveys words of comfort by saying the

\begin{abstract}
"Imma dihamu edaku, unangbe patukkihu naung lao laoma, namangoluonma siparesohon, unangho holan di jabu, ikkon lao marsaor tu akka parsaoranmu nasomal, ikkon lao ho maronan, nion baen paronanmu (dengan memberikan uang), lao ho tu parpunguan dohot margareja, nion baen durung-durungmu (dengan memberikan uang). Molo adong akka paradaton ihutton donganmu, nion baen narikkot tusi (dengan memberikan uang). Ate edaku, unangbe sai tangisda". It means: "For you, my edaku, do not drag on with sorrow, let go, let go of life. Don't just stay at home. Return to activity as usual. Go to the market, this is just your shopping (by giving money). Go to gatherings and churches. This is for your offering (by giving money). If there is a custom event, come with your friends. This is for that purpose (by giving money). I see, Peda, don't be sad anymore.
\end{abstract}

After finishing, then proceed with giving words of advice or comfort to family members who have been left by the deceased.

\title{
1. To the late wife
}

Words of advice delivered hula to the late wife by saying the words:

"Songonima tutu diho itoku, huboto jala hutanda jolma na burju do ho, jolma nasatia jala togu marhaporseaon, pos do rohaku dipanadingni laeku naburju nahinan. Dang gabe manimbil ho sian haporseaonmu, ikkon sahat do sude sakkapni lae nahinan tu akka berekon alani ho Duma, tangiangmima mandongani ibotoku". Meaning: "For you itoku, I know and know you a very good person. Faithful and faithful person. I am sure, after the death of my good brother, you will not fall away from your faith. You should be able to fulfill all your husband's wishes for all this cold. Our prayers are always with you ".

\section{To all children left behind}

Words of advice that bones convey to all children left behind by saying the words:

"Tuhamu sude bereku, unang gabe mandele, gale, gok nasomarama na tinanda, alai sahat do gabe, sangap jala mamora. Radothamu manungkun baritani inongmunaon di huta, urupanmu inongmunaon, ate bereku". Meaning: "To all of you frozen, don't despair. Many orphans, but still successful, respected and lucky. Always ask for news about your mother in the village, help your mother, it's frozen".

3. To the whole family of the deceased and friends of the same village

Words of thanks are conveyed hula to the entire family of the deceased and with the relatives of the village by saying the words:

"Dihamu keluarga ni laenami dohot dihamu dongan sahutani ibotokon, takkas do hubereng hami akka nauli akka nadenggan nanibaenmuna tu ibokon mulai sian namarujung ngolu sahat tuna tataruhon lae nahinan tu inganan parsatongkinanni. Songon hula-hula nasida au, 
holan hata mauliate naboi hupasahat tu hamu. Songon hatani natua-tua ma dohonokku "Balittangma pagabe tumudalhon sitadoan, arini hamu namarmaranggi dohot dongan sahutama gabe ala takkan dihamu marsipaolo-oloan. Aek marjullak-jullakma, namarjullakjullak di batu, jullak-jullak nai binaen tu tabu-tabu, hata pasu-pasu dohot poda nauli sian hami hula-hula, appu hamu ma martonga di jabu, songonima hata sian hami, mauliate". Meaning: "For our whole lae family, we are also relatives of our Ito village, obviously I see your good deeds for itoku. Since he died until we were delivered to his burial place. As a hula they thank you that I can convey to all of you. Like what the elders always say: "The weaver as a yarn spinner turns his back to his tool. The lives of you brothers and relatives. Because you understand each other. Sprinkling bubbly water on the rocks, the spark was put into taboos. Thanks to you and good advice from you in this house. Thus our words of encouragement, thank you".

After finishing, then answer from the protocol:

"Immatutu, mauliate ma dihamu hula-hula nami, takkas do huboto jala hebereng hami holong muna tu hami, mauliate ma tulang, anggiatma di jalo badan name, peak di simajujung name jala appe tu ibaranami. Songon didokni natua-tuama tutu dohonon name: Turtu ni anduhur tio tio inna lote, hata pasu pasu dohot hata gabe sian hamu tutur sai unangmai muba jala unangma mose. Jumani sappulu pituma tu jumani sappulu walu, hata pasu pasu sian hamu hula-hula name appuon namima martongani jabu. Sahat-sahat ni solu sai sahatma tu bottean nunga sahat diungkap hamu tujungni borumu inongnami sai sahat ma hita horas jala gabean. Emmatutu (jawab seluruh yang hadir). Meaning: "Thank you for our hula hula, we have seen proof of your love for us. Thank you bones. May our bodies accept it, stay in our heads and rest on our shoulders. As the elders say: Turtu voices are turtledove, tio-tio voices, prayers of blessing and hope that you convey, do not change. From seventeen to eighteen, we welcome our words of comfort and blessing, we welcome you. The boat sails to the harbor. It's finished, you unveil your veil, our mother, we wish you happiness and prosperity. Amen (answer all present).

Then the program closed with a closing prayer by hula-hula.

From the description of the discussion above, it can be summarized the number of words in open tujung can be seen in Table 4.1. below this.

Table 4.1. Amount of data and presentation in illocution speech acts.

\begin{tabular}{|c|l|c|c|}
\hline Number & \multicolumn{1}{|c|}{ Illocution Speech Acts } & $\begin{array}{c}\text { Amount } \\
\text { Data }\end{array}$ & $\begin{array}{c}\text { Percentage } \\
(\%)\end{array}$ \\
\hline 1 & $\begin{array}{l}\text { Speech Directive (speech request, order, invite, force, suggest, urge, } \\
\text { order, collect, order, urge, plead, challenge, give the command) }\end{array}$ & 21 & 51,22 \\
\hline 2 & $\begin{array}{l}\text { Representative Speech (speech demands, acknowledges, shows, } \\
\text { reports, gives testimony, mentions, speculates) }\end{array}$ & 16 & 39,02 \\
\hline 3 & $\begin{array}{l}\text { Expressive Speech (Speech, thank, complain, congratulate, flatter, } \\
\text { praise, blame, and criticize) }\end{array}$ & 4 & 9,76 \\
\hline & \multicolumn{1}{|c|}{ Total } & $\mathbf{4 1}$ & $\mathbf{1 0 0}$ \\
\hline
\end{tabular}

For more details this can be seen in Fig. 4.1. below this.

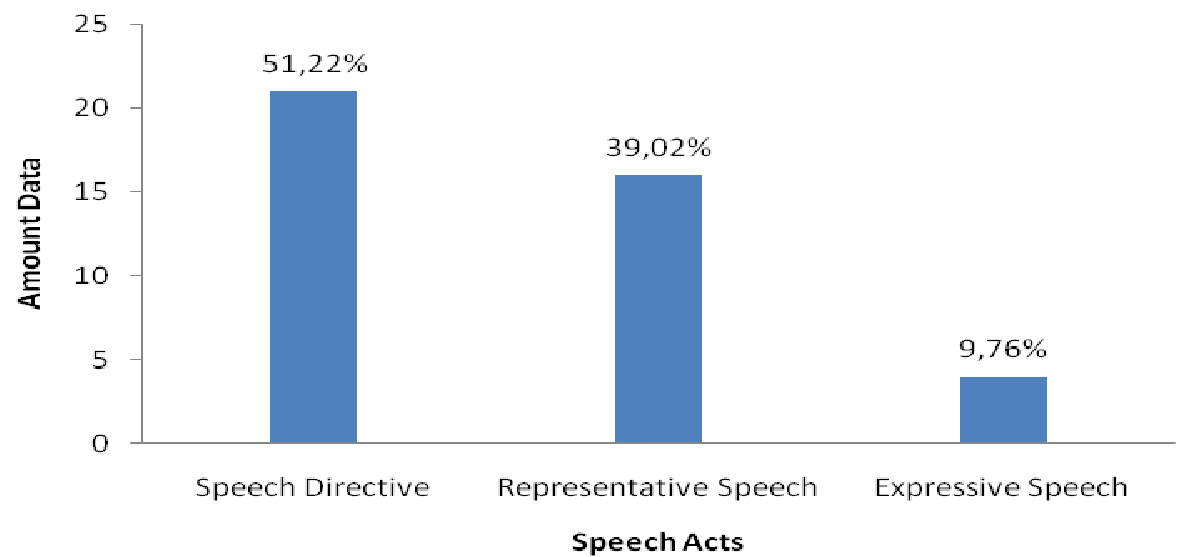

Fig. 4.1. Graph and percentage of speech types at the time of opening in the event of the death of Saurmatua. 


\section{Conclusions and Suggestions}

Conclusion

From the results of the research and discussion that has been carried out, several conclusions can be drawn, including:

1. Types of speech acts used in opening tujung at the event of death saurmatua adat community Batak Toba in Kabupaten Samosir is a type of illocution speech act.

2. The most dominant type of speech act is used in opening tujung at the event of death saurmatua adat community Batak Toba in Samosir Regency is directive utterance (speech request, order, invite, force, suggest, urge, order, collect, order, urge, request, challenge, give cue) of 21 data (51.22\%), representative speech (speech demands, acknowledges, shows, reports, gives testimony, mentions, speculates) of 16 data (16 39.02\%), and expressive speech (speech of thanking, complaining, congratulating, flattering, praising, blaming, and criticizing) of 4 data $(9.76 \%)$. The types of speech acts in the Batak Toba Saurmatua Death Ceremony are dominated by the types of directive speech acts.

\section{Suggestion}

Funerals saurmatua should still be preserved related to the concept of "ideal death", done by not overloading the children's economy, and in expressing gratitude to God for the blessings of long life, Until the day he died, he still had the chance to see all his children who were married (even had grandchildren). However, this ceremony is difficult if the Christian Batak community does not experience a pleasant and beneficial experience from the ceremony. A critical, sensitive, and wise attitude needs to be developed so that the ceremony of the death of saurmatua continues to undergo transformation towards a better direction, so that it can be accepted by all levels of Batak society (even not only those who are Christians).

\section{REFERENCES}

Abdul. 2004. General Linguistics. Jakarta: PT. Rineka Cipta.

Arikunto, S., 2010. Research Procedure A Practical Approach. Jakarta: PT. Rineka Cipta.

Cohen, A.D., 1996. 'Speech acts'. In N. H. Hornberger \& S. L. McKay. Sociolinguistics and Language Teaching. Cambridge: CUP

Denzin. 2009. N. K., and Lincoln, Y. Handbook of Qualitative Research. Translated by Dariyatno. Issue ke-1. Yogyakarta: Pustaka Pelajar

Harahap, B.H., 1987. Orientation of Batak Cultural Values. Jakarta: Sanggar Williem Iskandar.

Hasibuan, J., 1985. Art Et Culture: Batak Culture and Art. Jakarta: PT. Jaya Karta Agung Offset.

Hasugian, R.M., 2017. Ceremony of the Death Saurmatua of the Batak Toba: Analysis of Oral Traditions. Journal LINGUA, Vol. 14, No. 2, September 2017 p-ISSN: 1979-9411; e-ISSN: 2442-238X

J.C. Vergouwen. 1986. Society with Toba Batak Laws. Jakarta; Pustaka Azet.

Leech, Geoffrey. 1993. Pragmatic Principles. Jakarta: UI Press.

Malmkjer, K., 2006. The Linguistics Encyclopedia. London: Routledge

Moleong, Lexy J., 2007. Qualitative Research Methodology. Bandung: PT. Remaja Rosda Karya.

Nababan, P.W.J., 1987. Pragmatics: Theory and Its Application, Jakarta: Department of Education and Culture. Niessen, SA., 1985. Motifs of Life In Toba Batak Texts dan Textiles. Belanda: Foris Publications.

Rahardi, K., 2005. Pragmatics: Politeness of Indonesian Language Imperatives. Jakarta: PT. Erlangga.

Rajagukguk, I.S., 2015. Speech Act on Giving Ulos in the Death Ceremony of Saurmatua Adat Batak Toba (Pragmatic Study).

Rohmadi, M., 2004. Pragmatics: Theory and Analysis. Yogyakarta: PT. Lingkar Media.

Rustono. 1999. Pragmatic Principles. Semarang: IKIP Semarang Press.

Siahaan, N., 1982. Adat Dalihan Na Tolu, Principles and Implementation. Jakarta: PT. Tulus Jaya.

Sihombing. T.M., 1989. Jambar Hata: Dongan Tu Ulaon Adat. Jakarta: CV. Tulus Jaya.

Simorangkir, O.P., 2006. Idols, Customs and Religion: Christian Batak Studies. Jakarta: Yayasan Lobu Harambir

Sinaga, R., 2010. Pedigree of Batak clans. Jakarta: Dian Utama.

Situmorang I.M., and Bahrul Khair Amal. 2016. The existence of Ulos at the Sarimatua Death Ceremony in the Toba Batak Society.

Wardhaugh, R., 2006. An Introduction to Sociolinguistics. Oxford: Blackwell Publishing. 